\title{
Preparation of lasagnas with dried mix of tuna and tilapia
}

\author{
Katia Setsuko KIMURA ${ }^{1}$, Maria Luiza Rodrigues de SOUZA ${ }^{1 \star}$, Eliane GASPARINO ${ }^{1}$, \\ Jane Martha Graton MIKCHA ${ }^{2}$, Ana Paula Sartorio CHAMBÓ ${ }^{3}$, Rafaela VERDI ${ }^{1}$, Melina Franco CORADINI ${ }^{3}$, \\ Diego Rodrigues MARQUES ${ }^{4}$, Andresa FEIHRMANN 5 , Elenice Souza dos Reis GOES ${ }^{6}$
}

\begin{abstract}
The aim of this study was to develop a lasagna pasta enriched with dried mix of tuna (30\%) and tilapia (70\%) and formulate ready lasagna with enriched pasta. Lasagna pasta was elaborated with increasing levels (0, 5, 10 and $15 \%)$ of dried mix. Moisture, lipids and calories were not different between the inclusion levels; crude protein and ash increased linearly, carbohydrates reduced linearly, according to increasing levels of inclusion. There was an increase in n-3 and n-6 fatty acids with the inclusion of mix in lasagna. Between lasagna prepared with different sauces (tuna, chicken and bolognese), and pasta with $15 \%$ mix, it was observed that tuna lasagna had lower moisture content and higher protein, lipids, ash, carbohydrates and calories. All lasagna showed optimal sensory acceptance, indicating that the inclusion of $15 \%$ dried mix of tilapia and tuna in the pasta is feasible to improve the nutritional composition of lasagna.
\end{abstract}

Keywords: fish processing waste; pasta enrichment; Oreochromis niloticus; Thunnus sp.

Practical Application: Lasagnas with fish dehydrated mix have high nutritional value and great sensory profile.

\section{Introduction}

In recent years, as a result of changes in the lifestyle of people, it has been observed a high growth in the ready meals market (Masey \& Caldwell, 2007; Olivera \& Salvadori, 2012). Among the huge variety of ready, chilled or frozen foods, pasta is very popular and has a high degree of acceptability (Olivera \& Salvadori, 2006).

These pasta products, such as lasagna, can have their nutritional value increased by adding non-traditional ingredients to their formulation without apparent loss of quality (Petitot et al., 2010). Several studies have shown that the inclusion of protein concentrates from fish or fish meal into sweet and savory products can increase the nutritional value of the product (Ibrahim, 2009; Godoy et al., 2010; Coradini et al., 2015), including of pasta (Goes et al., 2016).

This increased nutritional value of the food is because fish has high quality protein, rich in essential amino acids, and represent a good source of B vitamins and a wide array of minerals including phosphorus, magnesium, iron, zinc and iodine in marine fish (Ariño et al., 2013). Moreover, marine fish, such as tuna, are rich in omega-3 polyunsaturated fatty acids, and its consumption is associated with many health benefits, mainly by reducing the incidence of cardiovascular disease (Walker et al., 2013; Marik \& Varon, 2009).

Considering the growing demand for products ready to serve, such as lasagna, the study of ways to improve their nutritional profile are important, and one way of doing this would be through the inclusion of fishmeal into their formulation. Therefore, the aim of this study was to include different levels of dried mix of tuna and tilapia into lasagna pasta, evaluating the nutritional value (chemical composition, fatty acid profile and calorie content), physical analysis (water activity and $\mathrm{pH}$ ), sensory and microbiological aspects, as well as to evaluate different flavors of lasagna with pasta enriched with dried mix of tuna and tilapia.

\section{Material and methods}

\subsection{Preparation of the dried mix of tuna and tilapia}

The mix contained tuna trunk (Tunnus sp.), provided by the company Gomes da Costa (Itajaí, SC, Brazil), and carcasses of Nile tilapia (Oreochromis niloticus), obtained from the company Smart Fish (Rolândia, PR, Brazil).

To obtain a more effective result as the acceptance of the product by consumers, it was used the mix of Nile tilapia meal and tuna meal. The mixture was chosen to improve the sensory characteristics of the final product, because the tuna has pronounced aroma and flavor, while the tilapia has mild aroma and flavor.

Tilapia meal was prepared with carcasses (spine and ribs without fins and head), which were cleaned by removing the kidneys, excess fat and visceral remains, washed and cooked for 
60 minutes in a pressure cooker with $0.005 \%$ BHT antioxidant. Next, the content was pressed (10 tons) for the extraction of excess water, used in cooking, subsequently ground in a meat mill and oven-dried at $60{ }^{\circ} \mathrm{C}$ for 24 hours. The dried material was subjected to a new grinding in knife mill, and then the product was vacuum packed for later use.

For preparing tuna meal, trunks (meat without spines, without the fins and head) were subjected to the same process used in the production of tilapia meal, but with shorter cooking time, only 20 minutes.

The dried mix was prepared with 30\% tuna meal and 70\% tilapia meal. From this dried mix, it was determined the percentage of inclusion of treatments to be used in the preparation of pasta and lasagna.

Dried mix of fish was packaged in plastic bags and stored at $-18 \pm 2{ }^{\circ} \mathrm{C}$ until physical and chemical analysis and preparation of pasta for lasagna.

\subsection{Preparation of tuna lasagna with inclusion levels of dried mix of tuna and tilapia into the pasta}

In the formulation of pastas, were included different levels $(0,5,10$ and $15 \%)$ of dried mix of tuna and tilapia, according to ingredients listed in Table 1.

Table 1. Ingredients for preparation of lasagna pasta.

\begin{tabular}{lcccc}
\hline \multirow{2}{*}{\multicolumn{1}{c}{ Ingredients }} & \multicolumn{4}{c}{ Inclusion levels } \\
\cline { 2 - 5 } & $0 \%$ & $5 \%$ & $10 \%$ & $15 \%$ \\
\hline Wheat Flour (g) & 1500 & 1425 & 1350 & 1275 \\
Dried mix of tuna and tilapia (g) & 0 & 75 & 150 & 225 \\
Eggs (g) & 560 & 668 & 639 & 597 \\
Salt (g) & 22 & 22 & 22 & 22 \\
Saffron (g) & 1.5 & 1.5 & 1.5 & 1.5 \\
Water (mL) & 100 & 40 & 20 & - \\
\hline
\end{tabular}

Ingredients were mixed to form a dough, which was kneaded until the proper consistency for passing the electric cylinder. Pastas were packed and chilled $\left( \pm 5^{\circ} \mathrm{C}\right)$ until preparation of lasagna and the analyses.

After production of the pastas, lasagnas were made with tuna sauce. we prepared a tuna sauce containing canned tuna in chunks (10.02\%), tomato (16.45\%), ready tomato sauce $(13.62 \%)$, tomato extract $(10.22 \%)$, onion $(14.92 \%)$, black pepper $(0.02 \%)$, sugar $(0.21 \%)$, butter $(2.00 \%)$, monosodium glutamate $(0.16 \%)$, water $(30.05 \%)$, chimichurri $(0.10 \%)$ dried parsley $(0.10 \%)$, corn starch $(0.30 \%)$, fried garlic $(0.63 \%)$, soybean oil $(0.20 \%)$ and complete seasoning with pepper $(1.00 \%)$. For the preparation of the lasagne, layers of pasta, tuna sauce and mozzarella cheese were alternated.

For pastas (before assembling the lasagna), analyses were made for water activity, $\mathrm{pH}$, chemical composition and calorific value. For tuna lasagna with different inclusion levels of dried mix of tuna and tilapia, microbiological analyses were performed as well as analyses for chemical composition and calorific value, fatty acid and sensory profile. For this purpose, we used samples from three replications for each treatment, thus composing a composite sample.

\subsection{Preparation of lasagnas of different flavors using pastas with 15\% inclusion of dried mix of tuna and tilapia}

Using the pastas with the inclusion of $15 \%$ dried mix of tuna and tilapia (Table 1) we prepared tuna, chicken and bolognese lasagnas. The sauces were made from the cooking of the ingredients presented in Table 2. For the assembly of lasagna, spread different layers of pasta, sauce and mozzarella cheese.

Of these lasagnas, analyses were made for microbiological analysis, proximate composition, calorific value and sensory analysis.

Table 2. Ingredients used for preparation of lasagna sauces using pasta with $15 \%$ inclusion of dried mix of tuna and tilapia.

\begin{tabular}{|c|c|c|c|c|c|}
\hline \multicolumn{2}{|c|}{ Tuna sauce } & \multicolumn{2}{|l|}{ Chicken sauce } & \multicolumn{2}{|c|}{ Bolognese sauce } \\
\hline \multicolumn{2}{|c|}{ Ingredients (\%) } & \multicolumn{2}{|l|}{ Ingredients (\%) } & \multicolumn{2}{|c|}{ Ingredients (\%) } \\
\hline Canned tuna in chunks & 10.02 & Breast chicken cooked and shredded & 18.30 & Ground beef & 20.44 \\
\hline Tomato & 16.45 & Complete seasoning & 0.79 & Complete seasoning & 1.16 \\
\hline Ready tomato sauce & 13.62 & Monosodium glutamate & 0.02 & Tomato extract & 11.61 \\
\hline Tomato extract & 10.22 & Salt & 0.41 & Ready tomato sauce & 19.74 \\
\hline Onion & 14.92 & Black pepper & 0.02 & Water & 23.22 \\
\hline Black pepper & 0.02 & Onion & 15.78 & Wheat flour & 0.58 \\
\hline Sugar & 0.21 & Milk & 63.10 & Onion & 23.22 \\
\hline Butter & 2.00 & Wheat flour & 1.58 & Black pepper & 0.03 \\
\hline Monosodium glutamate & 0.16 & & & & \\
\hline Water & 30.05 & & & & \\
\hline Chimichurri & 0.10 & & & & \\
\hline Dried parsley & 0.10 & & & & \\
\hline Corn starch & 0.30 & & & & \\
\hline Fried garlic & 0.63 & & & & \\
\hline Soybean oil & 0.20 & & & & \\
\hline Complete seasoning & 1.00 & & & & \\
\hline
\end{tabular}




\subsection{Microbiological analysis}

Microbiological analyses of lasagnas pastas and lasagnas with different sauces were made for the most probable number (MPN) of coliforms at $35^{\circ} \mathrm{C} /$ gram and $45^{\circ} \mathrm{C} /$ gram, count of coagulase positive staphylococci in colony forming unit (CFU/gram), Bacillus cereus count (CFU/gram) and Salmonella sp., using the methodology described by American Public Health Association (2001).

\subsection{Physical and chemical analysis}

Water activity of samples of lasagna pasta was determined with the aid of a water activity meter (Aw Sprint - Novasina $\mathrm{TH}-500)$. The $\mathrm{pH}$ of the samples was measured using $3 \mathrm{~g}$ sample diluted and homogenized in $50 \mathrm{~mL}$ distilled water. This mixture was subjected to the electrodes of the $\mathrm{pH}$ meter (DM 22, Digimed, São Paulo, Brazil) for 5 minutes for $\mathrm{pH}$ reading (Instituto Adolfo Lutz, 1985).

Also, we determined moisture, protein and ash content of the pastas and the lasagnas according to the methodology of the Association of Official Analytical Chemists (2005). Lipid extraction was performed according to the methodology of Bligh \& Dyer (1959). Carbohydrate content was carried out by the difference of the other components (Brasil, 2003). The total calorific value was obtained by summing the multiplication of the mean values of protein, lipid and carbohydrate multiplied by the factors 4, 9 and 4, respectively (Souci et al., 2000).

For analysis of fatty acids of lasagnas with inclusion levels of dried mix of tuna and tilapia into the pasta, approximately $100 \mathrm{mg}$ lipid was transmethylated according to Hartman \& Lago (1973), using solution of ammonium chloride and sulfuric acid in methanol as esterifying agent. Esters of fatty acids were isolated and analyzed by Agilent gas chromatograph, model 7890A, coupled to an Agilent 5975C mass detector, using a ZB-Wax Polyethylene Glycol column (30 m length $\times 0.25 \mathrm{~mm}$ internal diameter $\times 0.25 \mu \mathrm{m}$ thick film). The carrier gas was helium $(\mathrm{He})$ and the injection flow rate was $1 \mathrm{~mL} / \mathrm{min}$, split 1:10. The initial temperature of the column was set at $50^{\circ} \mathrm{C}$, hold for 2 minutes, and then raised to $220^{\circ} \mathrm{C}$ at a rate of $4{ }^{\circ} \mathrm{C} / \mathrm{min}$ and maintained for 7 minutes. The injector temperature used was $250^{\circ} \mathrm{C}$. The identification of fatty acids was performed by comparison of retention times of the methyl esters of the samples with those of authentic standards (Sigma).

\subsection{Sensory analysis}

The sensory analysis of lasagna with inclusion levels $(0,5,10$ and $15 \%)$ of dried mix of tuna and tilapia was performed with 72 untrained panelists, whereas the sensory analysis of lasagna of different flavors (tuna, chicken and bolognese) was performed with 50 untrained panelists. Methods of sensory analysis was approved by the Comitê Permanente de Ética em Pesquisa com Seres Humanos (COPEP) of the Universidade Estadual de Maringá, Maringá PR Brazil (Protocol 458.151/2013-COPEP, November 2013). The samples (around $25 \mathrm{~g}$ ) were offered to the tasters on a disposable plastic plate, and each sample was identified by three random numbers. A water bottle was offered with the samples to remove any residual flavor from the mouth.
Both sensory tests evaluated the parameters aroma, flavor, color and texture, using a 9 point-hedonic scale, where $1=$ dislike extremely and $9=$ like extremely, as Dutcosky (2011). With these parameters, the Acceptability Index was calculated according to Expression 1 (Dutcosky, 2011)

$$
I A \%=\frac{\text { average score of the product }}{\max \text { imum score }} \times 100
$$

Purchase intent was measured using a 5 point-hedonic scale, where 5 represented the highest score "definitely buy" and 1 represented the minimum score "definitely would not buy" (Dutcosky, 2011).

\subsection{Statistical analysis}

Data of sensory analyses were subjected to UNIVARIATE procedure of Statistical Analysis System (SAS, SAS Inst. Inc. Cary, NC, USA), to verify the assumptions of analysis of variance. It was considered the effect of treatment and panelists, testing the inclusion against the control, by means of testing and the behavior of the scores of panelists according to the inclusion of tuna protein concentrate. Variables of proximate composition were subjected to regression analysis at $5 \%$ level of significance. The fatty acid profile of the samples and microbiological analyses were used only to characterize the products.

\section{Results and discussion}

\subsection{Microbiological analysis}

There was a concentration of $<1 \times 10^{2} \mathrm{CFU} / \mathrm{g}$ of positive coagulase Staphylococcus and $<1 \times 10^{2} \mathrm{CFU} / \mathrm{g}$ of Bacillus cereus $(\mathrm{CFU} / \mathrm{g})$ in the microbiological profile of lasagnas with different inclusion levels of dried mix of tuna and tilapia and of different flavors, with pastas containing $15 \%$ dried mix of tuna and tilapia. All samples showed that coliforms at 35 and $45{ }^{\circ} \mathrm{C}$ were less than $3 \mathrm{MPN} / \mathrm{g}$, whereas research on Salmonella sp. indicate its absence in 25 grams of each sample examined. Results of the microbiological analysis showing that all lasagnas were fit for human consumption and within the microbiological standards required by the Brazilian law (Brasil, 2001).

\subsection{Water activity analysis and $\mathrm{pH}$}

Mean values of water activity concerning the lasagna pastas ranged from 0.420 to 0.537 , with a gradual increase according to increasing inclusion levels of the mix (Table 3). This may be because this fish meal contains high content of minerals, especially calcium, which has a hygroscopic potential, retaining part of the water in its structures. The mean value of Aw of the dried mix was 0.485 .

Table 3. Water activity (AW) and ph of lasagna pastas with inclusion of dried mix of tuna and tilapia.

\begin{tabular}{ccccc}
\hline & \multicolumn{4}{c}{ Inclusion levels } \\
\cline { 2 - 5 } & $0 \%$ & $5 \%$ & $10 \%$ & $15 \%$ \\
\hline $\mathrm{Aw}$ & 0.446 & 0.420 & 0.440 & 0.537 \\
$\mathrm{pH}$ & 6.45 & 6.52 & 6.53 & 6.56 \\
\hline
\end{tabular}


Water activity in foodstuffs is important for the development of microorganisms, and foods with high values (above 0.90 ) are very likely to suffer microbiological contamination, since diluted solutions of foods serve as a substrate for the growth of microorganisms. Therefore, our findings indicate that the lasagnas would have less risk of contamination by microorganisms, for having low water activity (Celestino, 2010).

The lasagna pastas with inclusion of dried mix of tuna and tilapia showed $\mathrm{pH}$ between 6.45 and 6.56, considered slightly acidic (Nespolo et al., 2014). In pasta, Resta \& Oliveira (2013) observed $\mathrm{pH}$ ranging from 5.69 to 6.12 , lower than those observed in this study.

\subsection{Chemical composition and calorific value}

The dried mix of tuna and tilapia presented mean values of $7.61 \%, 62.16 \%, 10.18 \%, 24.45 \%$ and $1.16 \%$ for moisture, crude protein, lipids, ash and phosphorus, respectively. These values indicate that the mix is a protein food with high content of lipids and ash, similar to the values reported by Souza et al. (2016) for tilapia, tuna, salmon and sardine meals.

The proximate composition of lasagna pastas with different inclusion levels of dried mix of tuna and tilapia is shown in Table 4. Values of moisture, lipids and calorific value were not significantly different $(\mathrm{P}>0.05)$ between the inclusion levels, but there was a linear increase $(\mathrm{P}<0.05)$ for crude protein and ash with addition of inclusion levels of the dried mix. Furthermore, there was a linear reduction $(\mathrm{P}<0.05)$ in the carbohydrate content of the pasta.

Crude protein content increased from 7.64\% (pasta without mix inclusion) to $11.27 \%$ in pasta with $15 \%$ inclusion of dried mix of tuna and tilapia. This increase is beneficial, since fish and derivatives have high biological value proteins with balanced amino acid profile (Neves et al., 2004), which may improve amino acid profile of pasta like lasagna, once wheat-based pastas are usually limiting in two of the eight essential amino acids: lysine and threonine (Sabanis et al., 2006).

Furthermore, the increase in ash content (from 0.99 for $0 \%$ inclusion to $2.70 \%$ for $15 \%$ inclusion) also contributes to improving the nutritional value, since fish is a source of calcium and phosphorus, but also contains iron, copper and selenium (Sartori \& Amancio, 2012).

The carbohydrate content decreased from $33.65 \%$ (pasta without mix inclusion) to $29.28 \%$ ( $15 \%$ inclusion), pointing out that the addition of dried mix of tuna and tilapia is effective for improving the nutritional profile of lasagna pasta. Similar results were obtained by Goes et al. (2016), who included different levels $(0,10,20$ and $30 \%)$ of tilapia meal into fresh pasta and verified a linear increase in lipid and ash content, with a decrease in carbohydrate content.

The proximate composition of ready lasagna with tuna sauce with different levels of dried mix of tuna and tilapia in the pasta is found in Table 5. Values of the proximate composition of ready lasagnas were different from those obtained for the pasta, since there were no differences $(\mathrm{P}>0.05)$ in moisture, protein, lipids, carbohydrates and calorific value of lasagnas. Only the ash content showed a significant effect $(\mathrm{P}<0.05)$ for the different inclusion levels; with higher ash values (3.70 and 3.66\%) observed for 10 and $15 \%$ inclusion levels, respectively).

Thus, the effect of adding the dried mix of tuna and tilapia into the lasagna pasta was weakened or disguised by components used in the assembly of lasagna, such as sauce and mozzarella. These changes probably stem from the fact that mozzarella and tuna sauce are rich in protein, minerals and fat.

Table 4. Proximate composition and calorific value of lasagna pastas with different inclusion levels of dried mix of tuna and tilapia.

\begin{tabular}{|c|c|c|c|c|c|}
\hline \multirow{2}{*}{ Parameters (\%) } & \multicolumn{4}{|c|}{ Inclusion levels } & \multirow{2}{*}{ P-value } \\
\hline & $0 \%$ & $5 \%$ & $10 \%$ & $15 \%$ & \\
\hline Moisture & $55.77 \pm 0.04$ & $56.25 \pm 0.01$ & $56.07 \pm 0.24$ & $55.06 \pm 0.06$ & 0.1499 \\
\hline Protein & $7.64 \pm 0.25$ & $8.54 \pm 0.2$ & $10.04 \pm 0.06$ & $11.27 \pm 0.35$ & $<0.0001^{*}$ \\
\hline Lipid & $1.96 \pm 0.01$ & $1.42 \pm 0.01$ & $1.46 \pm 0.01$ & $1.70 \pm 0.01$ & 0.3317 \\
\hline Ash & $0.99 \pm 0.06$ & $1.53 \pm 0.03$ & $2.12 \pm 0.02$ & $2.70 \pm 0.04$ & $<0.0001^{\star *}$ \\
\hline Carbohydrates & $33.65 \pm 0.35$ & $32.25 \pm 0.18$ & $30.31 \pm 0.14$ & $29.28 \pm 0.34$ & $<0.0001^{* * *}$ \\
\hline Calorific value (kcal/100g) & $182.78 \pm 0.42$ & $175.99 \pm 0.12$ & $174.56 \pm 0.90$ & $177.43 \pm 0.08$ & 0.0980 \\
\hline
\end{tabular}

${ }^{*} \mathrm{Y}=7.51+0.25 \times \mathrm{R}^{2}=0.98 ;{ }^{* *} \mathrm{Y}=0.97+0.11 \times \mathrm{R}^{2}=0.99 ;{ }^{* *} \mathrm{Y}=33.63-0.30 \mathrm{x} \mathrm{R}^{2}=0.98$

Table 5. Proximate composition of ready lasagnas prepared with pasta with different inclusion levels of dried mix of tuna and tilapia.

\begin{tabular}{|c|c|c|c|c|c|}
\hline \multirow{2}{*}{ Parameters (\%) } & \multicolumn{4}{|c|}{ Inclusion levels } & \multirow{2}{*}{ P-value } \\
\hline & $0 \%$ & $5 \%$ & $10 \%$ & $15 \%$ & \\
\hline Moisture & $48.55 \pm 6.01$ & $56.66 \pm 9.38$ & $44.90 \pm 3.47$ & $50.11 \pm 4.94$ & 0.6083 \\
\hline Protein & $16.28 \pm 3.21$ & $14.60 \pm 3.27$ & $18.91 \pm 1.26$ & $17.06 \pm 1.33$ & 0.1968 \\
\hline Lipids & $6.62 \pm 0.94$ & $5.08 \pm 1.40$ & $6.44 \pm 0.74$ & $5.91 \pm 0.53$ & 0.7088 \\
\hline Ash & $3.20 \pm 0.77$ & $2.78 \pm 0.36$ & $3.70 \pm 0.3$ & $3.66 \pm 0.51$ & $0.0419^{*}$ \\
\hline Carbohydrates & $25.36 \pm 2.51$ & $20.89 \pm 4.93$ & $26.04 \pm 1.70$ & $23.26 \pm 2.64$ & 0.8659 \\
\hline Calorific value (kcal/100g) & $226.11 \pm 25.48$ & $187.66 \pm 42.16$ & $237.78 \pm 16.28$ & $214.49 \pm 20.46$ & 0.8019 \\
\hline
\end{tabular}

\footnotetext{
$* \mathrm{Y}=2.99+0.05 \times \mathrm{R}^{2}=0.17$.
} 
Maluf et al. (2010) analyzed fresh pasta dough with inclusion of smoked fish and registered higher values than the lasagna pasta of this study (Table 4) for crude protein (15.21\%), lipids (9.73\%), ash (2.18\%) and carbohydrates (40.61\%). These values are closer to those obtained for the ready lasagna (Table 5).

For lasagnas prepared of different flavors, all the parameters of the proximate composition (Table 6) showed significant differences $(P<0.01)$ between the lasagnas; the lasagna with tuna sauce had the lowest moisture content (50.11\%). Also, tuna lasagna exhibited the highest values for protein (17.06\%), lipids (5.91\%), ash (3.66\%), carbohydrates (23.26\%) and calorific value $(214.49 \mathrm{kcal} / 100 \mathrm{~g})$. The chicken and bolognese lasagnas presented similar values for chemical composition and calorific value.

\subsection{Fatty acid profile}

There were 19 fatty acids in lasagna with tuna sauce with different inclusion levels of dried mix of tuna and tilapia in the pasta (Table 7). Of these, $58 \%$ are unsaturated including omega- 3 , -6 and -9 fatty acids, and $42 \%$ are saturated.

In detailing the lipid profile of ready lasagna, it was observed the presence of important essential fatty acids for human nutrition, especially the monounsaturated ones, such as palmitoleic (1.00 to $1.38 \%$ ), oleic (20.84 to $23.48 \%$ ), linolenic (1.19 to $1.47 \%$ ) and linoleic acid (13.30 to $15.90 \%)$ acids, among others.

The fatty acids of greater representativeness in ready lasagna included palmitic (22.38 to $26.42 \%)$, oleic (22.84 to $23.48 \%$ ),

Table 6. Proximate composition and calorific value of lasagnas of different flavors made with pasta containing different inclusion levels of dried mix of tuna and tilapia.

\begin{tabular}{lcccc}
\hline \multirow{2}{*}{ Parameters (\%) } & \multicolumn{3}{c}{ Lasagna flavor } & Bolognese \\
\cline { 2 - 4 } & \multicolumn{1}{c}{ Tuna } & Chicken & $61.44 \pm 0.01 \mathrm{a}$ & \\
\hline Moisture & $50.11 \pm 2.02 \mathrm{~b}$ & $62.84 \pm 0.02 \mathrm{a}$ & $12.90 \pm 0.12 \mathrm{~b}$ & 0.001 \\
Crude protein & $17.06 \pm 0.54 \mathrm{a}$ & $14.13 \pm 0.06 \mathrm{~b}$ & $4.60 \pm 0.10 \mathrm{~b}$ & 0.0004 \\
Lipids & $5.91 \pm 0.21 \mathrm{a}$ & $4.98 \pm 0.06 \mathrm{~b}$ & $3.10 \pm 0.03 \mathrm{ab}$ & 0.003 \\
Ash & $3.66 \pm 0.21 \mathrm{a}$ & $2.63 \pm 0.03 \mathrm{~b}$ & $17.96 \pm 0.06 \mathrm{~b}$ & 0.011 \\
Carbohidrates & $23.26 \pm 1.08 \mathrm{a}$ & $15.43 \pm 0.13 \mathrm{~b}$ & $164.83 \pm 0.65 \mathrm{~b}$ & 0.001 \\
Calorific value $(\mathrm{kcal} / 100 \mathrm{~g})$ & $214.49 \pm 8.35 \mathrm{a}$ & $163.04 \pm 0.26 \mathrm{~b}$ & 0.001 \\
\hline
\end{tabular}

Mean values in the same row followed by different letters are significantly different by Tukey's test. Data presented as mean \pm standard deviation.

Table 7. Fatty acid profile of ready lasagna with tuna sauce and different inclusion levels of dried mix of tilapia and tuna into the pasta.

\begin{tabular}{|c|c|c|c|c|}
\hline \multirow{2}{*}{ Fatty acids $(\mathrm{g} / \mathrm{kg})$} & \multicolumn{4}{|c|}{ Inclusion levels } \\
\hline & $\mathbf{0 \%}$ & $5 \%$ & $10 \%$ & $15 \%$ \\
\hline C10:0 Capric Acid & 0.93 & 1.07 & 1.26 & 1.31 \\
\hline C12:0 Lauric Acid & 1.27 & 1.47 & 1.67 & 1.76 \\
\hline C14:0 Myristic Acid & 5.58 & 6.36 & 7.00 & 7.24 \\
\hline C16:0 Palmitic Acid & 22.38 & 25.1 & 26.05 & 26.42 \\
\hline C16:1n-7 Palmitoleic Acid & 1 & 1.2 & 1.3 & 1.38 \\
\hline C17:00 Margaric Acid & 0.38 & 0.47 & 0.46 & 0.46 \\
\hline C17:1 n-9 Heptadecenoic Acid & 0.14 & 0.2 & 0.2 & 0.19 \\
\hline C18:0 Stearic Acid & 8.68 & 10.29 & 9.8 & 9.8 \\
\hline C18:1n-9 Oleic Acid & 20.84 & 23.06 & 22.6 & 23.48 \\
\hline C18:1 n-7 Vaccenic Acid & 2.33 & 2.64 & 2.61 & 2.6 \\
\hline C18:2n-6 Linoleic Acid & 13.3 & 13.97 & 13.84 & 15.19 \\
\hline C18:3n-3 Linolenic Acid & 1.19 & 1.34 & 1.36 & 1.47 \\
\hline C18:2 CLA & 0.48 & 0.59 & 0.6 & 0.53 \\
\hline C20:1 n-9 Eicosanoic Acid & 0.17 & 0.33 & 0.2 & 0.21 \\
\hline C20:2 n-6 Eicosadienoic Acid & 0.22 & 0.14 & 0.19 & 0.12 \\
\hline C20:3 n-9 Eicosatrienoic Acid & 0.17 & 0.14 & 0.14 & 0.37 \\
\hline C20:4 Arachidonic Acid & 0.41 & 0.41 & 0.48 & 0.22 \\
\hline C20:5 n-3 Eicosapentaenoic Acid (EPA) & 0.15 & 0.38 & 0.29 & 0.22 \\
\hline C22:00 Behenic Acid & 0.1 & 0.25 & 0.26 & 0.16 \\
\hline Sum of saturated fatty acids (SFA) & 39.32 & 45.01 & 46.5 & 47.15 \\
\hline Sum of monounsaturated fatty acids & 24.48 & 27.43 & 26.91 & 27.86 \\
\hline Sum of polyunsaturated fatty acids (PUFA) & 15.92 & 16.97 & 16.9 & 18.12 \\
\hline PUFA/SFA ratio & 0.41 & 0.38 & 0.36 & 0.38 \\
\hline Sum of n-3 fatty acids & 1.34 & 1.72 & 1.65 & 1.69 \\
\hline Sum of n-6 fatty acids & 13.52 & 14.11 & 14.03 & 15.31 \\
\hline n-6/n-3 ratio & 10.09 & 8.20 & 8.50 & 9.06 \\
\hline
\end{tabular}


linoleic (13.30 to $15.19 \%$ ), stearic (8.68 to $10.29 \%$ ) and myristic (5.58 to 7.28). Of these, two are present with higher frequency in foods of animal origin, especially in beef, and have greater hypercholesterolemic or atherogenic potential: myristic (14:0) and palmitic (16:0) acids (Driskell, 2006), which together account for approximately $30 \%$ of total fatty acids in ready lasagna (Table 6).

Marine fish have a diet with a greater proportion of $n-3$ fatty acids, in turn, freshwater fish have a higher $n-6 / n-3$ ratio than marine fish (Olsen, 1998; Zenebe et al., 1998). This ratio was $10.09,8.20,8.50$ and 9.06 for lasagnas with $0,5,10$ and $15 \%$ inclusion of dried mix of tilapia and tuna, respectively.

\subsection{Sensory analysis}

For lasagnas with tuna sauce with different inclusion levels of dried mix of tuna and tilapia into the pasta (Figure 1a), there were no differences $(\mathrm{P}>0.05)$ for aroma, flavor, color, texture and acceptance rate. Mean values for color varied between 7.63 and 7.93, and for texture, from 7.22 to 7.56. For aroma, the mean preference by the tasters ranged from 7.53 to 7.93 , and for flavor, from 7.31 to 7.81 . These values are considered good because, according to Dutcosky (2011), seven means like moderately, indicating good acceptance of the product by tasters regardless of the treatment, which allows us to infer that the
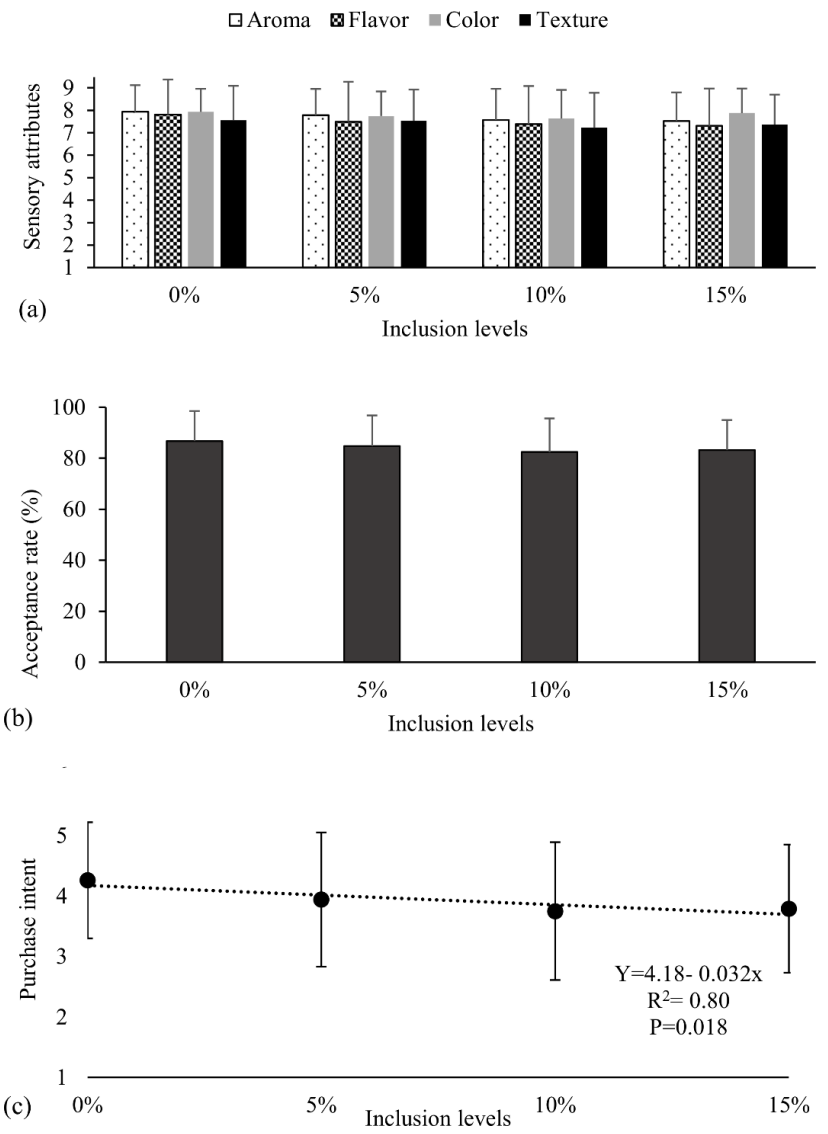

Figure 1. Sensory analysis of ready lasagna with tuna sauce and pasta with inclusion of dried mix of tilapia and tuna. (a) Sensory attributes (P-value $>0.05)$; (b) Acceptance rate (P-value $=0.0867)$; (c) Purchase intent $(\mathrm{P}$-value $=0.018)$. Vertical bars represent the standard deviation of the mean. use of up to $15 \%$ inclusion of tilapia and tuna mix is feasible to maintain the sensory quality of lasagna.

The sensory analysis of pasta dough enriched with smoked fish made by Maluf et al. (2010) also attained a great success, with nearly $90 \%$ of tasters approving the pasta and the overall evaluation of attributes, such as color, flavor, aroma and texture, achieved values ranging between good and very good.

As for purchase intent (Figure 1c), there was a linear reduction $(\mathrm{P}<0.05)$ of scores $\left(\mathrm{Y}=4.18-0.032 \mathrm{x} \mathrm{R}^{2}=0.80\right)$. However, since there were no differences $(\mathrm{P}>0.05)$ for the acceptance rate (Figure 1b), which was above $80 \%$ for all lasagnas, it appears that the lasagnas with inclusion of dried mix of tilapia and tuna was very well accepted by the panelists, as Dutcosky (2011) recommends a minimum acceptance of $70 \%$ for the product is considered well accepted.

The results obtained herein can be compared to those reported by Marengoni et al. (2009), which, when tested four fishburger formulations, also detected no differences in the mean parameters assigned to flavor, aroma, tenderness, overall appearance and purchase intent, averaging respectively, 7.14 and $7.44 ; 7.14$ and $7.46 ; 7.30$ and $7.42 ; 7.21$ and $7.35 ; 3.86$ and 3.98. These results similar to those observed in the present study; fishburgers were between moderately and very well accepted,
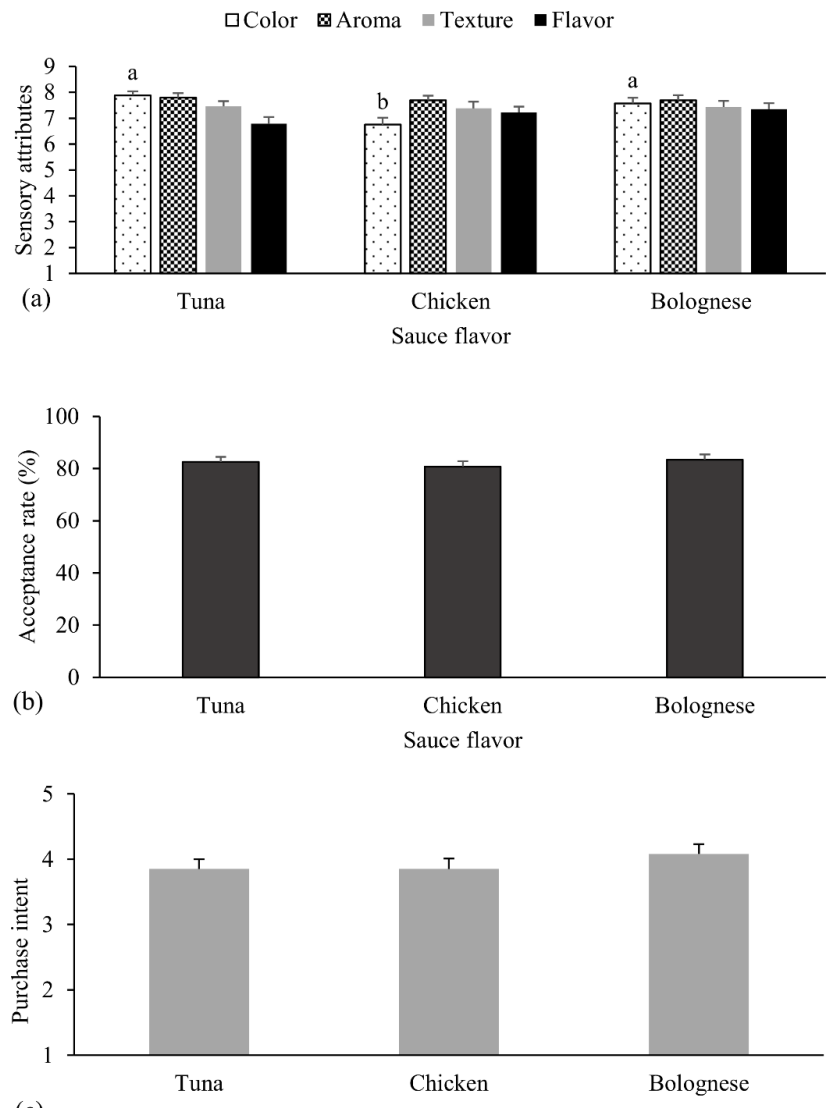

(c)

Sauce flavor

Figure 2. Sensory analysis of lasagnas with different sauces with $15 \%$ inclusion of dried mix of tuna and tilapia. (a) Sensory attributes (for color, P-value $=0.001$ - different letters are significantly different by Tukey's test.); (b) Acceptance rate (P-value $=0.635)$; (c) Purchase intent $(\mathrm{P}$-value $=0.493)$. Vertical bars represent the standard deviation of the mean. 
without preference for a specific, evidencing the good acceptance of fish derived products. High values of acceptance were also recorded by Veit et al. (2012), who included Nile tilapia fillet into carrot cake (88.58\%) and chocolate cake (89.99\%).

In sensory analysis of lasagnas with different sauces (Figure $2 \mathrm{a})$, only the color was significantly different $(\mathrm{P}<0.01)$, with the lowest acceptance for lasagna with white sauce (chicken). The other attributes showed high acceptance rate $(82.59 \%$ for tuna, $80.79 \%$ for chicken and $83.40 \%$ for bolognese) (Figure 2b), and purchase intent (Figure 2c).

Regarding the acceptance rate, the pasta with 15\% inclusion of dried mix of tilapia and tuna can be used without any problems, that is, it was highly accepted by panelists and there was addition of protein and minerals in lasagnas.

\section{Conclusions}

The inclusion of dried mix of tilapia and tuna into lasagna pasta improves its nutritional composition, increasing its content of protein and minerals, besides reducing the carbohydrate content. Ready lasagna with tuna sauce and inclusion of dried mix of tilapia and tuna show a good fatty acid profile and optimal acceptance rate. The inclusion of $15 \%$ dried mix of tilapia and tuna into the pasta for lasagna with sauces of chicken, tuna or bolognese is feasible to improve the nutritional value of the product, presenting a good sensory acceptance.

\section{Acknowledgements}

The authors would like to thank the CNPq (Conselho Nacional de Desenvolvimento Científico e Tecnológico), Fundação Araucária and the company Gomes da Costa (Itajaí - SC).

\section{References}

American Public Health Association - APHA. (2001). Compendium of methods for the microbiological examination of foods. Washington, DC: APHA.

Ariño, A., Beltrán, J. A., Herrera, A., \& Roncalés, P. (2013). Fish and seafood: nutritional value. In B. Caballero. Encyclopedia of human nutrition (3th ed., pp. 254-261). Waltham: Elsevier. http://dx.doi. org/10.1016/B978-0-12-375083-9.00110-0.

Association of Official Analytical Chemists - AOAC. (2005) Official methods of analyses of the association of analytical chemists (18th ed.). Washington, DC: AOAC.

Bligh, E. G., \& Dyer, W. J. (1959). A rapid method of total lipid extraction and purification. Canadian Journal of Biochemistry and Physiology, 37(8), 911-917. PMid:13671378. http://dx.doi.org/10.1139/o59-099.

Brasil. Ministério da Saúde. (2001, January 2). Regulamento técnico sobre padrões microbiológicos para alimentos (RDC no 12 , de 02 de janeiro de 2001. Diário Oficial [da] República Federativa do Brasil.

Brasil. Ministério da Saúde. (2003, December 23). Aprova o regulamento técnico sobre rotulagem nutricional de alimentos embalados (RDC $\mathrm{n}^{\circ}$ 360, de 23 de dezembro de 2003). Diário Oficial [da] República Federativa do Brasil.

Celestino, S.M.C. (2010). Princípios de secagem de alimentos. Planaltina: Embrapa Cerrados.

Coradini, M.F., Souza, M.L.R., Verdi, R., Goes, E.S.R., Kimura, K.S. \& Gasparino, E. (2015). Quality evaluation of onion biscuits with aromatized fishmeal from the carcasses of the Nile tilapia. Boletim do Instituto de Pesca, 41(esp.): 719- 728.

Driskell, J. A. (2006). Sports nutrition: fats and proteins. Boca Raton: CRC.

Dutcosky, S. D. (2011). Análise sensorial de alimentos (3 ed., 239 p., Coleção Exatas). Curitiba: Champagnat.

Godoy, L. C., Franco, M. L. R. S., Franco, N. P., Silva, A. F., Assis, M. F., Souza, N. E., Matsushita, M., \& Visentainer, J. V. (2010). Análise sensorial de caldos e canjas elaborados com farinha de carcaças de peixe defumadas: aplicação na merenda escolar. Ciência e Tecnologia de Alimentos, 30, 86-89. http://dx.doi.org/10.1590/ S0101-20612010000500014.

Goes, E. S. R., Souza, M. L. R., Michka, J. M. G., Kimura, K. S., Lara, J. A. F., Delbem, A. C. B., \& Gasparino, E. (2016). Fresh paste enrichment with protein concentrate of tilapia: nutritional and sensory characteristics. Ciência e Tecnologia de Alimentos, 36(1), 76-82. http://dx.doi.org/10.1590/1678-457X.0020.

Hartman, L., \& Lago, R.C.A. (1973). Rapid preparation of fatty acids methyl esters. Laboratory Practice, 22(6), 475-476.

Ibrahim, S. M. (2009). Evaluation of production and quality of saltbiscuits supplemented with fish protein concentrate. World Journal of Dairy and Food Sciences, 4(1), 28-31.

Instituto Adolfo Lutz - IAL. (1985). Normas analíticas do instituto Adolfo Lutz: métodos químicos e físicos para análise de alimentos. (2 ed.). São Paulo: IAL.

Maluf, M. L. F., Weirich, C. E., Dallagnol, J. M., Simões, M. R., Feiden, A., \& Boscolo, W. R. (2010). Elaboração de massa fresca de macarrão enriquecida com pescado defumado. Revista do Instituto Adolfo Lutz, 69, 84-90.

Marengoni, N. G., Pozza, M. S. S., Braga, G. C., Lazzeri, D. B., Castilha, L. D., Bueno, G. W., Pasquetti, T. J., \& Polese, C. (2009). Caracterização microbiológica, sensorial e centesimal de fishburgers de carne de tilápia mecanicamente separada. Revista Brasileira de Saúde e Produção Animal, 10, 168-176.

Marik, E., \& Varon, J. (2009). Omega-3 dietary supplements and the risk of cardiovascular events: a systematic review. Clinical Cardiology, 32(7), 365-372. PMid:19609891. http://dx.doi.org/10.1002/clc.20604.

Masey, R. M., \& Caldwell, D. G. (2007). Design of an automated handling system for limp, flexible sheet lasagna pasta. In IEEE International Conference on Robotics and Automation (pp. 1226-1231). http:// dx.doi.org/10.1109/ROBOT.2007.363152.

Nespolo, C. R., Oliveira, F. A., Pinto, F. S. T., \& Olivera, F. C. (2014). Práticas em tecnologia de alimentos. Porto Alegre: Artmed.

Neves, R. A. M., Mira, N. V. M., \& Marquez, U. M. L. (2004). Caracterização de hidrolisados enzimáticos de pescado. Ciência e Tecnologia de Alimentos, 24(1), 101-108. http://dx.doi.org/10.1590/ S0101-20612004000100019.

Olivera, D. F., \& Salvadori, V. O. (2006). Textural characterisation of lasagna made from organic whole wheat. International Journal of Food Science \& Technology, 41(2), 63-69. http://dx.doi.org/10.1111/j.13652621.2006.01382.x.

Olivera, D. F., \& Salvadori, V. O. (2012). Kinetic modeling of quality changes of chilled ready to serve lasagna. Journal of Food Engineering, 110(3), 487-492. http://dx.doi.org/10.1016/j.jfoodeng.2011.12.015.

Olsen, Y. (1998). Lipids and essential fatty acids in aquatic foods webs: what can freshwater ecologists learn from mariculture. In M. T. Arts \& B. C. Wainman. Lipids in freshwater ecosystems (chap. 8, pp. 161-202). New York: Springer. http://dx.doi.org/10.1007/9781-4612-0547-0_9

Petitot, M., Boyer, L., Minier, C., \& Micard, V. (2010). Fortification of pasta with split pea and faba bean flours: pasta processing and 
quality evaluation. Food Research International, 43(2), 634-641. http://dx.doi.org/10.1016/j.foodres.2009.07.020.

Resta, M. S. A., \& Oliveira, T. C. R. M. (2013). Avaliação do padrão estafilococos coagulase positiva estabelecido pela legislação brasileira para massas alimentícias. Brazilian Journal of Food Technology, 16(4), 319-325. http://dx.doi.org/10.1590/S1981-67232013005000038.

Sabanis, D., Makri, E., \& Doxastakis, G. (2006). Effect of durum flour enrichment with chickpea flour on the characteristics of dough and lasagne. Journal of the Science of Food and Agriculture, 86(12), 1938-1944. http://dx.doi.org/10.1002/jsfa.2567.

Sartori, A. G. O., \& Amancio, R. D. (2012). Pescado: importância nutricional e consumo no Brasil. Segurança Alimentar e Nutricional, 19(2), 83-93.

Souci, S. W., Fachman, H., \& Kraut, E. (2000). Foods composition and nutrition tables (1182 p.). Stuttgart: Medpharm GmbH Scientific Publishers.
Souza, M. L. R., Yoshida, G. M., Campelo, D. A. V., Moura, L. B., Xavier, T. O., \& Goes, E. S. R. (2016). Formulation of fish waste meal for human nutrition. Acta Scientiarum. Technology. In press.

Veit, J. C., Feiden, A., Boscolo, W. R., Freitas, M. B., Goes, E. S. R., Moore, O. Q., \& Finkler, J. K. (2012). Desenvolvimento e caracterização de bolos de chocolate e de cenoura com filé de tilápia do Nilo Oreochromis niloticus. Alimentos e Nutrição, 23, 427-433.

Walker, C. G., Jebb, S. A., \& Calder, P. C. (2013). Stearidonic acid as a supplemental source of $\omega-3$ polyunsaturated fatty acids to enhance status for improved human health. Nutrition (Burbank, Los Angeles County, Calif.), 29(2), 363-369. PMid:23102888. http://dx.doi. org/10.1016/j.nut.2012.06.003.

Zenebe, T., Ahlgren, G., Gustafsson, I. B., \& Boberg, M. (1998). Fatty acid and lipid content or Oreochromis niloticus L. in Ethiopian lakes: dietary effects of phytoplankton. Ecology Freshwater Fish, 7(3), 146-158. http://dx.doi.org/10.1111/j.1600-0633.1998.tb00181.x. 